\title{
M \\ A \\ $\mathbf{T}$ \\ E $\quad \mathbf{R}$ \\ I \\ A \\ $\mathbf{L}$ \\ STUDIA POLONIJNE \\ T. 41. LUBLIN 2020 \\ DOI: http://doi.org/10.18290/sp2041-17 \\ NATALIA JANOWIEC \\ WIZERUNEK JANA PAWLA II W PRASIE POLONIJNEJ USA NA PRZYKLADZIE ,DZIENNIKA ZWIĄZKOWEGO” I ,NOWEGO DZIENNIKA-POLISH WEEKLY"
}

Jan Paweł II był pierwszym w historii papieżem, który doceniał rolę, jaką odgrywają we współczesnym świecie środki masowego przekazu. Traktował media jako nowoczesną formę komunikacji, dzięki której Kościół katolicki mógłby wpływać na kształt życia społecznego i religijnego na świecie.

Niniejszy artykuł jest wstępną analizą wizerunku postaci Jana Pawła II w dwóch polonijnych tytułach prasowych ze Stanów Zjednoczonych: „Dzienniku Związkowym” i „Nowym Dzienniku-Polish Weekly”. Ze względu na ograniczone ramy tej publikacji przedstawiono jedynie krótką charakterystykę zagadnień, które zakwalifikowano jako istotne dla szerszego rozpoznania i zbadania tematu.

\section{JAN PAWEŁ II A PRASA}

Papież doceniał rolę i znaczenie prasy. W roku 1992 przestrzegał przed działalnością antyewangelizacyjną różnych środowisk redakcyjnych. Uważał, że niektórzy wydawcy mediów zechcą odgrywać zbyt dużą rolę w społeczeństwach, czego skutkiem będą: próba zniekształcania ludzkich postaw i wartości opartych na chrześcijaństwie, ośmieszanie przyjętych przez społeczeństwo zasad moralnych i najważniejszych prawd wiary, promocja patologii jako wzorców życiowych oraz kreacja Kościoła jako wroga współczesnej cywilizacji ${ }^{1}$. Federico Lombardi podkreśla, że rozeznanie mediów umożliwiło papieżowi podchodzenie do nich z dystansem i spokojem: „Papież dobrze wie, co chce i powinien powiedzieć, i z całą pewnością nie zmienia tego powodowany lękiem przed mediami albo sympatią do nich. Nie jest mu jednak obojętne, czy to, co mówi, zostanie zrozumiane, czy też nie"².

Mgr Natalia JANOwIEC - Instytut Historii i Dziedzictwa Kulturowego Uniwersytetu Papieskiego Jana Pawła II w Krakowie; e-mail: natalia.janowiec@onet.pl.

${ }^{1}$ Por. W. Kulbat, Jan Pawet II i media, http://www.niedziela.pl/artykul/24068/nd/Jan-Pawel-II-i-media [dostęp: 15.04.2020].

${ }^{2}$ F. Lombardi, Jan Pawet II i media, „L'Osservatore Romano” (wyd. pol.) 9(2003), s. 38. 
Według Jana Pawła II „dialog, szczerość i więź” to podstawy komunikowania się z prasą. W 1980 r. napisał:

Czytam regularnie prasę, a zwłaszcza tę, która mnie krytykuje. Jeżeli dziennikarze piszą o mnie w sposób pozytywny, interesując się każdym moim krokiem, to wszystko w porządku, ale to mniej ciekawe. Czytam przede wszystkim dzienniki lewicowe, ponieważ mnie krytykują pouczając, co powinienem robić... zastanawiam się nad tym, bo stale trzeba się uczyć. Czytam tę prasę właśnie dlatego ${ }^{3}$.

Jan Paweł II wykorzystywał zainteresowanie prasy swoją osobą. Za pośrednictwem wydarzeń katolickich, pielgrzymek, przemówień i wystąpień kierował jej uwagę w stronę różnych idei i spraw ukazywanych z perspektywy nauczania Kościoła. Andrzej M. Deskur zauważa, że to „nowa postawa” pozwalająca na dotarcie do szerszego kręgu odbiorców ${ }^{4}$. Podobnie twierdzi Rodrigo Taddei, który słowami Jana Pawła II istotnie definiuje znaczenie mediów, w tym prasy: „kształtują nie tylko upowszechniane treści, ale przede wszystkim nowe sposoby przekazu, nowe języki, nowe techniki i nowe postawy psychologiczne"

Według różnych badaczy źródłami szacunku, jaki otaczał wizerunek Jana Pawła II w prasie, były przede wszystkim: umiłowanie Boga i drugiego człowieka, prawda, prostota, szczerość i nadzieja: „Chrześcijanin - nauczał - winien głosić «dobrą nowinę», orędzie Chrystusa i z radością dzielić się nim z każdym człowiekiem dobrej woli, który potrafi go słuchać" ${ }^{\circ}$.

\section{ZARYS HISTORII PRASY POLONIJNEJ USA}

Za początek rozwoju prasy polonijnej w USA można uznać ukazanie się w $1863 \mathrm{r}$. pierwszego pisma pt. „Echo z Polski” w Nowym Jorku?

W latach dwudziestych XX wieku w USA istniało około 100 polskich tytułów prasowych ${ }^{8}$. Wśród pism największą popularność zyskały: „Gazeta Polska” (1873-1913),

3 Jan Pawet II w Ameryce Łacińskiej. Przemówienia i homilie, Warszawa 1980, s. 15-16.

${ }^{4}$ Jan Pawet II, Orędzie do uczestników Kongresu ds. Komunikacji Między Religiami, w: JaN Pawel II, Nauczanie papieskie, t. III, Poznań-Warszawa 1985, s. 609.

${ }^{5}$ Cz. DrĄżEK, Ewangelizacja przez media w nauczaniu Jana Pawła II, https://www.opoka.org. pl/biblioteka/T/TA/TAP/media_nau_jp2.html [dostęp: 20.04.2020].

${ }^{6}$ JAN PAwEe II, Niech Bóg obdarzy mocq $i$ wsparciem katolików działajacych w świecie środków społecznego przekazu! Orędzie na Światowy Dzień Środków Społecznego Przekazu (1992), „L'Osservatore Romano” 13(1992), nr 5, s. 5.

${ }^{7}$ Por. A. PAczKowski, Polonijna prasa, w: Encyklopedia PWN, https://www.encyklopedia.pwn. pl/haslo/polonijna-prasa;3959695.html [dostęp: 14.04.2020].

${ }^{8}$ Por. I. Leonowicz-Bukata, Media polonijne w USA, „Komunikacja Społeczna” 2012, nr 4, s. 45 . 
„Ameryka Echo” (1889-1971), „Gwiazda Polarna” (od 1902 r.), „Dziennik Polski” (od 1904 r.), „Nowy Dziennik” (od 1971 r.), „Dziennik Związkowy” (od 1908 r.).

Najbardziej rozpoznawalnymi tytułami wśród amerykańskiej prasy polonijnej są „Dziennik Związkowy” i „Nowy Dziennik-Polish Weekly”. , Dziennik Związkowy” powstał w roku 1908 jako organ Związku Narodowego Polskiego. Jest najstarszą i najbardziej wpływową gazetą na świecie o charakterze opiniotwórczym. Pierwszym redaktorem naczelnym gazety był Franciszek H. Jabłoński. W latach 2004-2007 nakład gazety wyniósł około 40 tys. egzemplarzy. Gazeta dociera również do Polski (m.in. do Kancelarii Sejmu, parlamentarzystów i biblioteki Uniwersytetu Warszawskiego) ${ }^{10}$.

Pierwszy numer „Nowego Dziennika-Polish Weekly” ukazał się w roku 1971. Obecnie utrzymuje pozycję największej i najbardziej prestiżowej polskojęzycznej gazety w USA. Pismo jest redagowane w New Jersey i w Nowym Jorku ${ }^{11}$. Gazeta opisuje bieżące wydarzenia społeczne, polityczne, sportowe, kulturalne i religijne.

\section{WYBRANE KWESTIE METODOLOGICZNE}

Przegląd publikacji odnoszących się do wybranych zagadnień dotyczących pontyfikatu Jana Pawła II w prasie polonijnej USA pozwala stwierdzić, że osoba papieża wzbudzała zainteresowanie wśród jej czytelników. W najbardziej popularnych dziennikach: „Dzienniku Związkowym” i „Nowym Dzienniku-Polish Weekly” w latach 2007-2020 występowała spora liczba publikacji będących omówieniami rozmaitych aspektów postawy i nauczania Jana Pawła II. Pod względem gatunków medialnych były to wywiady, informacje, felietony oraz artykuły publicystyczne.

Wybrane elementy analizy jakościowej najbardziej charakterystycznych publikacji uzupełniono ukazaniem (w zarysie) wybranych kontekstów charakterystycznych dla wizerunku Jana Pawła II na podstawie kategorii takich, jak: 1) przywódca religijny jako autorytet moralny w relacjach z rządzącymi, 2) przewodnik ludzkości promujący moralne wzorce zachowań (życie społeczne), 3) obrońca życia poczętego, wykazujący troskę o każde dziecko (ochrona ludzkiego życia), 4) apostoł Chrystusa wzywający do nawrócenia i wiary w jego Bóstwo (nauczanie), 5) obrońca rodzin jako wspólnot życia, jej praw i godności (życie w rodzinie), oraz 6) promotor prawd i wartości chrześcijańskich (świętość).

${ }^{9}$ Por. A. Paczkowski, Polonijna prasa.

${ }^{10}$ Por. W.A. WierzewsKi, Kiedy pisanie pozwalało zaistnieć. Wspomnienia z lat działalności dziennikarskiej w prasie polonijnej w Ameryce, 1981-2002, w: Autoportret zbiorowy. Wspomnienia dziennikarzy polskich na emigracji z lat 1945-2002, red. W. Piątkowska-Stepaniak, Opole: Uniwersytet Opolski 2003, s. 302-303.

${ }^{11}$ Por. Historia powstania, http://www.dziennik.com/ [dostęp: 23.04.2020]. 


\section{WIZERUNEK JANA PAWŁA II W DZIENNIKACH}

Osoba Jana Pawła II szczególny oddźwięk znajduje w „Dzienniku Związkowym” i „Nowym Dzienniku-Polish Weekly”. Pierwszy z dzienników koncentruje się na opisie postawy Jana Pawła II wobec aspektów politycznych, moralnych i społecznych.

Wątek wcześniejszych relacji papieża z amerykańskimi prezydentami znalazł interesujące przywołanie w kilku publikacjach. W artykule Jan Pawet II $i$ USA: sympatia, sojusz i obawy o los ojczyzny demokracji autor wyjaśnił, że papieżowi bardzo zależało na wzajemnych relacjach i współpracy z prezydentami. Szczególnie wiele uwagi dziennik poświęcił analizie relacji papieża z Ronaldem Reaganem i George W. Bushem.

W publikacjach takich, jak: Papież: «solidarność» stowem kluczem nauki społecznej Jana Pawła II, Jan Pawet II i medycyna, Blisko Boga i drugiego człowieka, Papież do Polaków: wypraszajmy pokój dla świata, Franciszek: św. Jan Pawet II zabiegał o to, by Kościót stat na straży praw człowieka, Papież Franciszek o Janie Pawle II: byt wielkim świadkiem Chrystusa, Jan Pawet II najlepiej postrzegana osobistościa społeczna ostatniego stulecia publikowano wypowiedzi papieża, prezydentów, publicystów na temat godności ludzkiej, ochrony ludzkiego życia, sprzeciwu wobec komunizmu, solidarności i pokojowej współpracy międzynarodowej.

Dziennik dostarcza sporo publikacji w formie prywatnych świadectw ludzi i refleksji nad osobą Jana Pawła II. W artykułach pojawiają się również wypowiedzi papieża dotyczące wspomnianej kwestii poszanowania godności ludzkiej i wartości życia. Warto przytoczyć w tym miejscu kilka tytułów: Panie Boże, o pokój Cię proszę!, Wizyta papieża Jana Pawła II w Chicago, W hotdzie papieżowi św. Janowi Pawtowi II, Santo subito, To papież wszystkich ludzi, Wspominając Świętego Jana Pawła II, Papież literat. Przyczynek do rozmowy, Na zawsze pozostanie w pamięci rodaków w Chicago - Jan Pawet II.

Drugi z dzienników koncentruje tematykę swoich publikacji wokół rodziny w świetle nauczania papieża. W publikacjach takich, jak: Jan Pawet II - papież życia, mitości i rodziny, Nie lękajcie się, otwórzcie na oścież drzwi Chrystusowi, Jan Pawet II wciąz do nas mówi..., Tutaj czuje się ducha św. Jana Pawta II ukazuje pochwałę akceptacji, miłości, szacunku, życzliwości i empatii jako wartości szczególnie bliskich każdej podstawowej komórce społecznej.

Wśród treści publikowanych często pojawiają się także refleksje na temat poszanowania rodziny we współczesnym świecie. Interesująco widzi to autor artykułu Nie lękajcie się, otwórzcie na oścież drzwi Chrystusowi. Wychodzi on od stwierdzenia, że: „Bogatą spuściznę swojego nauczania o rodzinie zawarł w encyklikach, listach, a także homiliach wygłoszonych w Polsce, jak na przykład w Szczecinie czy w Nowym Sączu, gdy mówił o obronie rodziny, która jest kolebką życia, i zachęcał do odwagi przyjęcia nowego życia" 12 .

${ }^{12}$ Nie lękajcie się, otwórzcie na oścież drzwi Chrystusowi, http://www.dziennik.com/featured/ nie-lekajcie-sie-otworzcie-na-osciez-drzwi-chrystusowi/ [dostęp: 17.04.2020]. 
Dziennik opisuje świętość Jana Pawła II. Anna Arciszewska w artykule Wezwali go z dalekiego kraju... Mój papież wyjaśnia, że: „Dla wielu ludzi był symbolem dobra. Ci, którzy osobiście się z nim spotkali, mówią, że miał bardzo serdeczne, jakby pozaziemskie spojrzenie człowieka, który coś więcej reprezentuje niż swoją fizyczną obecność"13.

Świętość jako jedną z przewodnich idei pontyfikatu dostrzegł również Mariusz Jackowski (polski przewodnik po Watykanie) w wywiadzie udzielonym dla dziennika. Według jego zapatrywań: „Niektórym odejmowało mowę, inni tak się wzruszali, że nie mogli powstrzymać łez, wszyscy czuli jego świętość, choć za jego życia nikt o tym głośno nie mówił" ${ }^{14}$. Jeszcze dalej w ocenie papieskiej świętości poszedł fotograf Arturo Mari. Jego zdaniem dialog to jedna z cech świętości. Na łamach dziennika podkreślił, że papież: „Gdziekolwiek jechał, chciał widzieć się z ludźmi pokrzywdzonymi przez los, nawet jeżeli nie było tego w oficjalnej wizycie"15.

Świętość Jana Pawła II oparta na prawdzie i wartościach chrześcijańskich znajduje też odzwierciedlenie w tytułach publikacji: Jan Pawet II - święty w poezji, Byt świętym człowiekiem, 10. rocznica śmierci Jana Pawła II: to byt święty naszych czasów, Droga Jana Pawła II do świętości, Tu spacerowali święci, między innymi brat Albert i Jan Pawet II.

Omawiając wybrane publikacje dziennikarzy dotyczące wizerunku Jana Pawła II, należy stwierdzić, że poświęcili oni wiele miejsca temu zagadnieniu. Polskie tytuły polonijne przedstawiły osobę papieża $\mathrm{w}$ różnych aspektach.

Opisywano relacje Jana Pawła II z prezydentami Stanów Zjednoczonych oraz nauczanie. Wart podkreślenia jest fakt, że polonijni publicyści ukazywali też w osobie papieża najważniejsze wartości moralne, społeczne, wychowawcze i religijne.

Rodzina w nauczaniu Jana Pawła II, tuż obok innych wartości, była jednym z najczęściej poruszanych tematów na łamach „Nowego Dziennika-Polish Weekly”.

Godny uwagi jest fakt, że zarówno „Dziennik Związkowy”, jak i „Nowy Dziennik-Polish Weekly" w wizerunku Jana Pawła II starał się odnaleźć najważniejsze wartości moralne i religijne, co stanowi podstawę czerpania wzorcu autorytetu z osoby św. Jana Pawła II.

13 A. ArciszewsKa, Wezwali go z dalekiego kraju... Mój papież, http://www.dziennik.com/uncategorized/wezwali-go-z-dalekiego-kraju-moj-papiez [dostęp: 17.04.2020].

${ }^{14}$ A. SŁabISz, Byt świętym człowiekiem, http://www.dziennik.com/polonia/byl-swietym-czlowiekiem [dostęp: 17. 04.2020].

${ }^{15}$ Arturo Mari - świadek świętości, http://www.dziennik.com/polonia/arturo-mari-swiadek-swietosci [dostęp: 17.04.2020]. 


\section{BIBLIOGRAFIA}

Jan Paweł II w Ameryce Łacińskiej. Przemówienia i homilie, Warszawa: Instytut Wydawniczy PAX 1980, s. 15-16.

JAN PAweŁ II, Orędzie do uczestników Kongresu ds. Komunikacji Między Religiami, w: Jan Paweł II, Nauczanie papieskie, t. III, Poznań-Warszawa: Wydawnictwo Inne 1985, s. 609.

JAN PAWEŁ II, Niech Bóg obdarzy mocą i wsparciem katolików działających w świecie środków społecznego przekazu! Orędzie na Światowy Dzień Środków Społecznego Przekazu (1992), „L'Osservatore Romano” 13(1992), nr 5, s. 5-6.

LeONOwiCZ-BuKaŁa I., Media polonijne w USA, „Komunikacja Społeczna” 2012, nr 4, S. 45.

Lombardi F., Jan Paweł II i media, „L'Osservatore Romano” (wyd. pol.) 9(2003), s. 38.

WIERzEWSKI W.A., Kiedy pisanie pozwalało zaistnieć. Wspomnienia z lat działalności dziennikarskiej w prasie polonijnej w Ameryce, 1981-2002, w: Autoportret zbiorowy. Wspomnienia dziennikarzy polskich na emigracji z lat 1945-2002, red. W. Piątkowska-Stepaniak, Opole: Uniwersytet Opolski 2003, s. 302-303.

\section{Źródla internetowe}

ArciszewsKa A., Wezwali go z dalekiego kraju... Mój papież, http://www.dziennik.com/ uncategorized/wezwali-go-z-dalekiego-kraju-moj-papiez [dostęp: 17.04. 2020].

Arturo Mari - świadek świętości, http://dziennik.com/polonia/arturo-mari-swiadek-swietosci/ [dostęp: 17.04.2020].

DrĄżEK Cz., Ewangelizacja przez media w nauczaniu Jana Pawła II, https://opoka.org.pl/ biblioteka/T/TA/TAP/media_nau_jp2.html [dostęp: 20.04.2020].

Historia powstania, http://dziennik.com/ [dostęp: 23.04.2020].

KulbAT W., Jan Paweł II i media, http://www.niedziela.pl/artykul/24068/nd/Jan-Pawel-II-i-media [dostęp: 15.04.2020].

„Nie lękajcie się, otwórzcie na oścież drzwi Chrystusowi”, http://dziennik.com/featured/ nie-lekajcie-sie-otworzcie-na-osciez-drzwi-chrystusowi/ [dostęp: 17.04.2020].

PACZKowsKi A., Polonijna prasa, w: Encyklopedia PWN, https://encyklopedia.pwn.pl/ haslo/polonijna-prasa;3959695.html [dostęp: 14.04.2020].

SŁABISz A., Był świętym człowiekiem, http://dziennik.com/polonia/byl-swietym-czlowiekiem/ [dostęp: 17.04.2020]. 


\section{WIZERUNEK JANA PAWŁA II W PRASIE POLONIJNEJ USA \\ NA PRZYKŁADZIE „DZIENNIKA ZWIĄZKOWEGO” I ,NOWEGO DZIENNIKA-POLISH WEEKLY”}

\section{Streszczenie}

Jan Paweł II był pierwszym w historii papieżem, który doceniał rolę, jaką odgrywają we współczesnym świecie środki masowego przekazu. Traktował media jako nowoczesną formę komunikacji, dzięki której Kościół katolicki mógłby wpływać na kształt życia społecznego i religijnego na świecie.

Niniejszy artykuł jest wstępną analizą wizerunku postaci Jana Pawła II w dwóch polonijnych tytułach prasowych ze Stanów Zjednoczonych: „Dzienniku Związkowym” i „Nowym Dzienniku-Polish Weekly". Ze względu na ograniczone ramy tej publikacji przedstawiono jedynie krótką charakterystykę zagadnień, które zakwalifikowano jako istotne dla szerszego rozpoznania i zbadania tematu.

Słowa kluczowe: Jan Paweł II; prasa polonijna USA; „Dziennik Związkowy”; „Nowy Dziennik-Polish Weekly"

\section{THE IMAGE OF JOHN PAUL II IN THE POLISH PRESS IN THE USA: \\ THE EXAMPLE OF DZIENNIK ZWIAZZKOWY \\ AND NOWY DZIENNIK-POLISH WEEKLY}

\section{Summary}

John Paul II was the first pope in history to appreciate the role played by the media in the modern world. He perceived the media as a modern form of communication, through which the Catholic Church could influence the shape of social and religious life in the world.

This article is a preliminary analysis of the image of John Paul II in two Polish press titles published in the United States: Dziennik zwiazkowy and Nowy Dziennik-Polish Weekly. Due to the limited framework of this publication, the article presents only a brief description of the issues that have been recognised as important for a broader analysis of the topic.

Key words: John Paul II; Polish press in the USA; Dziennik Zwiazkowy; Nowy Dziennik-Polish Weekly 